Expanding Sanitary Infrastructure and the Shaping of River History : River Vantaa (Finland), 1876-1982

\title{
Schönach, Paula
}

2015-05-15

Schönach , P 2015 , ' Expanding Sanitary Infrastructure and the Shaping of River History :

River Vantaa (Finland), 1876-1982 ' , Environment and History , vol. 21 , no. 2 , pp. 201-226

. https://doi.org/10.3197/096734015X14267043141381

http://hdl.handle.net/10138/168840

https://doi.org/10.3197/096734015X14267043141381

Downloaded from Helda, University of Helsinki institutional repository.

This is an electronic reprint of the original article.

This reprint may differ from the original in pagination and typographic detail.

Please cite the original version. 
This is a pre-copy-editing, author-produced PDF of an article accepted following peer review for publication in Environment and History, Vol 21:2, 201-226.

The definitive publisher-authenticated version is available online,

doi: $\underline{10.3197 / 096734015 X 14267043141381}$

\title{
Expanding Sanitary Infrastructure and the Shaping of River History: River Vantaa (Finland) 1876-1982
}

\section{PAULA SCHÖNACH}

Department of Environmental Sciences

P.O.Box 65,

FIN-00014 University of Helsinki, Finland

Email: paula.schonach@helsinki.fi

\begin{abstract}
This article investigates the environmental history of the River Vantaa, southern Finland, and its interaction with the spatial development of water-related infrastructures in an urbanising environment. The article argues that the overlapping use of the river as part of both waste water and drinking water infrastructures has shaped its ecological characteristics and consequently influenced communities' possibilities for using it. As a response to hydrological alterations, human activity focused on increasingly manipulating the river water and its flow. The study describes a gradual spatial expansion of the hydrological territory of the Finnish capital and a process of increasingly heavy engineered alterations in order to meet the water-related needs of communities in the region. This happened within the watershed and beyond, both above and under the surface. The study covers the time period from 1876 to 1982.
\end{abstract}

KEYWORDS: River history, water supply, sanitary infrastructure, River Vantaa

\section{INTRODUCTION}

Water is one of the most essential resources that facilitate human life and wellbeing. Throughout history, rivers have been a crucially important natural environment for the supply of water to human beings. Rivers have been the subject of a great number of environmental historical studies. ${ }^{1}$ The inher-

1. Melosi 2011, 204. Edited volumes by Castonguay and Evenden (2012) and Mauch and Zeller (2008) hold a good selection of recent studies of river histories, mainly with an urban emphasis. Melosi (2011) offers a good bibliography of relatively recently published topics on various water and river related themes, especially from the US but also more broadly. 
ently dynamic nature of rivers has led scholars to adopt a view that emphasizes ongoing interchanges between the dynamics of natural processes and human intervention. Both the appearance and function of rivers have been changed by human activity, but, simultaneously, as rivers are themselves active agents, they are also driving forces in history. ${ }^{2}$

The importance of rivers for city development is widely acknowledged. The urban perspective in exploring river histories often includes controversies and tensions between upstream and downstream communities about the uses of riverine natural resources. As a flow resource, water transcends administrative and jurisdictional boundaries that usually do not coincide with hydrological boundaries. ${ }^{3}$ Thus, urban-rural or city-hinterland relationships and the spatial aspects connected to them are an essential part of river histories.

The multifaceted qualities of rivers make them subjects of disputes concerning such matters as water volume and the river's hydroelectric potential, the economic value in terms of fisheries or transportation routes or the waters' capacity to carry waste and wastewater away. These factors have made rivers an essential part of socio-natural-technological networks, infrastructures that are the material mediators of the water flows so essential for the functioning of modern cities and societies in general. ${ }^{4}$

The main task of several key infrastructural systems is to control natural processes and extract natural resources, or dispose of waste, for human benefit. ${ }^{5}$ Human dependence on natural resources is managed through the infrastructures that regulate the material fluxes, in the urban context often referred to as 'urban metabolism'. ${ }^{6}$ Infrastructure that regulates fluxes of water is a hybrid of man-made material constructions (pipes, pumping stations etc.) and natural elements (river bed, gravity). Together they convey the water over distances and make it available for management and manipulation, such as chemical treatment, regulation of flow and storage. They are by no means static constructs but continuously under observation, adjustment and improvement. ${ }^{7}$ As one river can be part of several infrastructural systems throughout the watershed it becomes a crucial node connecting different places with each other and with socio-natural-technical systems managing water flow. The water flow unites communities that otherwise have no obvious links. They

2. Mauch and Zeller 2008, 7 .

3. Bakker 2010, 199.

4. Tarr and Dupuy 1988, xiii; Joyce 2003, 70; Kaika 2005, 28. The concept of socio-technical networks is understood in the spirit of Thomas Hughes (1987), as integrative systems includ-ing physical objects, explicitly including natural elements such as rivers, social components and human infuence. See also Carse (2012) for the notion of nature as infrastructure.

5. Doyle and Havick 2009, 350.

6. Tarr 2002, 511.

7. Cf. Dagenais 2011, 108. 
become 'involuntary neighbours' through the flow of water, but also of sew-age, pollution and refuse. ${ }^{8}$

These mutual dependencies of locations along rivers and their water-sheds (and beyond) densify the hydrographic network, where urbanised areas tend to have a predominant role. One consequence of the intensification of infrastructurally-mediated material fluxes has been a spatial widening of the hydrological spheres of intervention that urbanising areas in particular impose on their hinterlands. The dense urban areas and their water related needs - both fresh water extraction and the disposal of wastewater - extend increasingly further away from the actual site of consumption and removal. In literature this has been described as increasing of the ecological footprint ${ }^{9}$ - or the extraterritorialities ${ }^{10}$ of water supply and disposal.

Numerous western cities started to develop networked structures for sup-plying citizens with purified and piped household water and the removal of wastewater during the nineteenth century. The adverse consequences of urbanisation and industrialisation had led to the recognition of the need for water purification and sewage infrastructure to improve sanitation and hygiene, a goal which resonated with the reformist spirit of the times. By the mid-twentieth century, the maturation of these infrastructure systems for regulating water and wastewater flows signified they had become normalised elements of modernity. As a consequence they had become standardised background processes, socially ignored and taken for granted by the public, until the occurrence of failures or even collapses. ${ }^{11}$ Infrastructure failures can be caused by a natural response to the use of resources. The inclusion of a riverine element exposes the infrastructural system and its engineering logic to the disruptions caused by natural characteristics of the physical environment, such as changes in ecology, flow patterns and chemical feedback processes. ${ }^{12}$ It demonstrates the constant interaction of riverine environments with the infrastructural systems they are part of and the socio-political framework they are bound to.

In this article I examine the environmental history of the River Vantaa (Vantaanjoki), southern Finland, and its role in the development of sanitary infrastructures in southern Finland. I approach the river as an integral part of the water supply and wastewater infrastructure of communities in the water-shed, especially the Finnish capital, Helsinki. The main task is to analyse how the overlapping infrastructural functions of the River Vantaa altered its water quality and how the responses of the riverine environment in turn affected the spatial organisation of those infrastructural functions.

8. Luckin 2001, 209. Cf. Kinnersley 1988, 2, cited in Taylor 2013, 2.

9. Tarr 2002, 511; Kaika 2005, 141.

10. Cf. Barles 2013.

11. Graham and Marvin 2001, 21, 44, 55-59.

12. Castonguay and Evenden 2012, 3. 
The importance of urban-hinterland interactions has been recognised in environmental history since the seminal work of William Cronon ${ }^{13}$ and this article follows this tradition by widening the geographical focus of the river history beyond both city and watershed limits and considering the spatial con-sequences of urban-riverine dependencies. ${ }^{14}$ While the environmental history of urban sanitary infrastructures in particular is widely explored ${ }^{15}$ and the notion of water bodies as common 'ultimate sinks" ${ }^{16}$ for wastes and pollution produced by humans has been attributed in literature, the analysis of rivers as part of vital infrastructures also outside the urban sphere is less common. ${ }^{17}$ Several river histories highlight the close connection and nearly inseparable nature of cities' interaction with rivers due to infrastructural networks. $^{18}$ This study shows a rare example of how this infrastructurally-defined relationship can also be disconnected. This article does not specifically focus on tensions between locations along the river caused by conflicting uses; rather I consider the functioning of the infrastructures that are intertwined in the river and its watershed. In the Finnish context, Timo Herranen has written a well-documented review of the history of the Helsinki Water Works. ${ }^{19}$ While it is a reliable source on the historical facts of certain events, it nevertheless views the water supply only from the view point of the Helsinki Water Works and lacks conceptually-based analysis of this infrastructural development, the role

\section{Cronon 1991.}

14. Work providing inspiration to this study has been Colten (2012), who analyses three river basins and the complex interactions of the physical riverine environment and the political economy of urban river transformations and, e.g., describes a very similar path of large alterations in the hydrologic regime at Lake Michigan due to dual uses of the water body for fresh water and sewage disposal. See also Soll (2012) on the regionality of New York City's water supply and Barles (2013) on the influence of Paris on the aquatic landscape of territories outside the urban area.

15. Urban environmental historians have dealt widely with the question of urban water sup-ply and wastewater infrastructure, especially in the North American and European context. Key issues have been, e.g., the development and diffusion of sanitary ideas and paradigms (Melosi 2000), the advancement of water related public works infrastructure (Goubert 1988; Guillerme 1988; Goubert 1989, esp. ch. 8; in the Finnish context see Turpeinen 1995; Katko 1997; Katko 2005; Juuti and Katko 2005), principles and technologies adopted in various citiies (e.g. Tarr 1996; Melosi 2000; Laakkonen 2001), and the scientifc unveiling of pollution caused by sewerage to riverine environments (Tarr 1996, esp. ch. 2). The notions of material fuxes and circulation and the concept of metabolism have been successfully applied in e.g. in Barles 2007; see also Winiwarter 2001) The temporal focus in the majority of works has been on the 19th and 20th centuries as this is when urban sanitary infrastructure was introduced on a large scale. In this respect the study at hand makes no exception.

16. Cf. Tarr 1996.

17. Carse (2012) powerfully applies the idea of nature as infrastructure in her study; an example of rivers as parts of infrastructures in urban settings is given by Collins, Muller and Tarr (2008), while Dagenais (2012) presents a case study of two infrastructural systems confict-ing within a river in an eventually urbanising context.

18. Castonguay and Evenden 2012, 238.

19. Herranen 2001. 
of the River Vantaa in it and detailed consideration of the broader societal, regional and spatial context.

The study at hand blends two time-scales, as it follows a century-long path of river-dependent sanitary infrastructure development and, on the other hand, analyses an abrupt historical event of infrastructure failure as a turning point in the river history. The analysis covers a time period from the latter half of the nineteenth century, when communal fresh water extraction from the river started to replace well-based water supply, until 1982, when the river was abandoned as the primary fresh water source for the capital. The main emphasis of the study is on the post-World War Two period, when the environmental condition of the river started to change more drastically and hence had a more significant influence on the political decisions made about the development of fresh water supply and waste water infrastructure in the region.

This article proceeds by first introducing the characteristics of the River Vantaa and its watershed. Thereafter, I explore the history of fresh water supply of Helsinki, the inclusion of the River Vantaa in this and its role as a wastewater sink. I then describe the quantitative and qualitative constraints that these infrastructures impose upon the river and consequent infrastructure failure. Finally, I consider the spatial expansion and increasing networking of water-related infrastructures in the region and place the river within this development.

\section{RIVER VANTAA, 'THE LIFE STREAM OF HELSINKI' ${ }^{20}$}

The River Vantaa, despite its rather small physical size, is one of Finland's most important rivers. It originates in the municipality of Hausjärvi, in the province of Southern Finland. With a catchment basin of 1,685 square kilometres, the main 100 -km-long riverbed runs southwards through the most densely populated and heavily utilised areas and landscapes of modern Finland. Diverse industrial facilities are located in the catchment; however, land use upstream has been dominated by agriculture, forestry and, during the twentieth century, increasingly urban settlements. The catchment area consists today of fourteen municipalities, with several rather small and seven larger population centres. ${ }^{21}$ The Finnish capital, Helsinki, is only partially included in the catchment area, leaving the most central and most populated areas outside (see Map 1).

The river has seven tributaries and a modest average flow of $16 \mathrm{~m}^{3} / \mathrm{s}$. The lakes account for only around two per cent of the river's drainage basin, and thus there is very little natural capacity to level changes in river flow. Extremes in flow thus vary greatly, from peak flows during spring foods of more than 300 $\mathrm{m}^{3} / \mathrm{s}$ to minimum flows of less than $2 \mathrm{~m}^{3} / \mathrm{s}$ during the summer months. The

20. The phrase is borrowed from Helsingin Sanomat 9 May 1982, 29.

21. Riihimäki, Hyvinkää, Järvenpää, Kerava, Hyrylä, Klaukkala, Vantaa. 


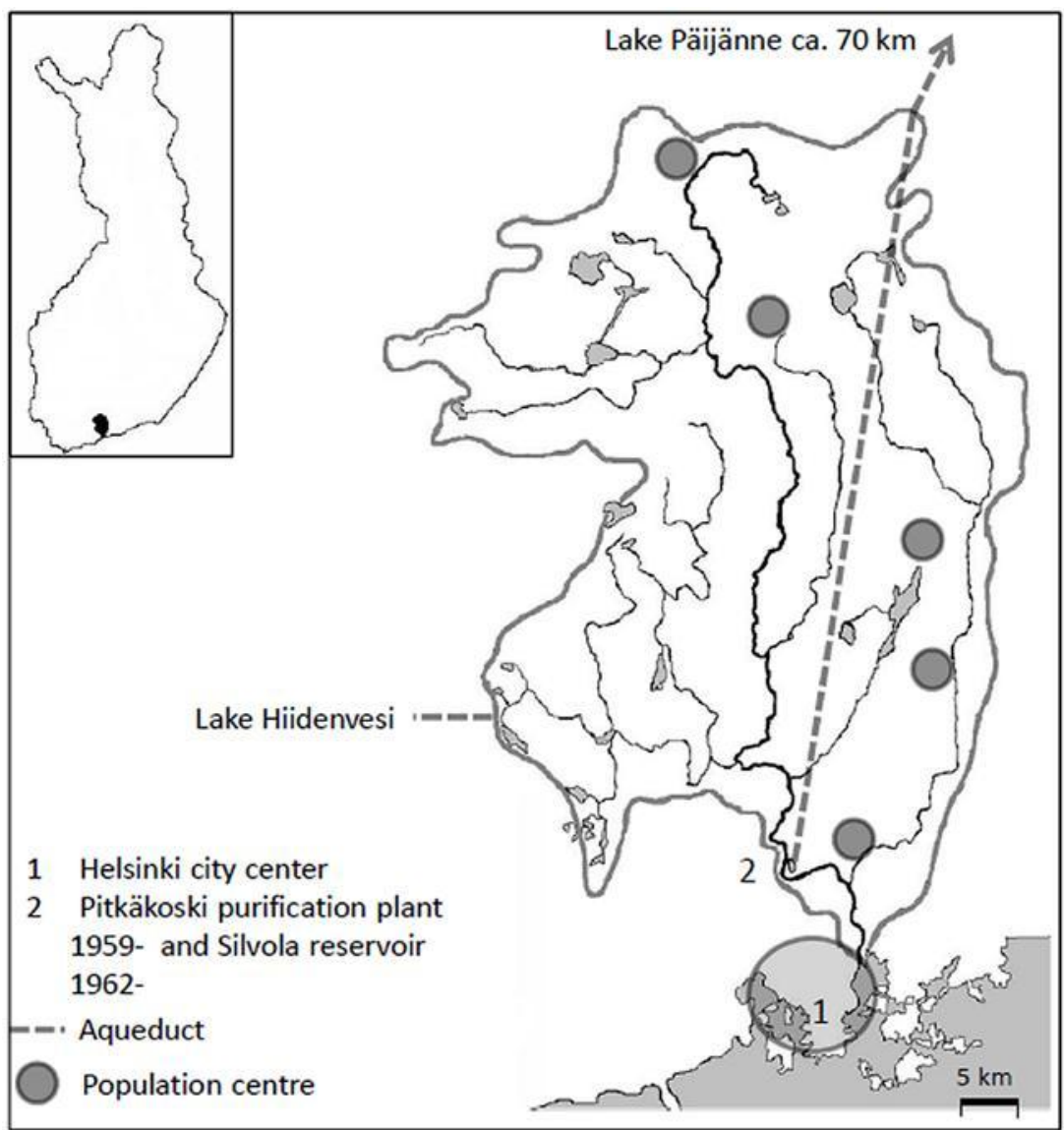

Map 1. The River Vantaa drainage basin with the tributaries, largest population centres and aqueducts for water supply. Adapted by the author from Vantaanjoen ja Helsingin seudun vesiensuojeluyhdistys 1965 and 1972.

average width of the river is seventeen metres, but it is considerably smaller upstream, where it is often said to be merely a ditch. The river catchment was once post-glacial seabed, and this is clearly visible in the high amount of clay in the catchment, which results in the dark, naturally muddy colour of the river water. $^{22}$

22. The environmental history of the river has been touched upon by some previous studies. Rahikainen (2001) and Timmerbacka (2006) have explored the history of the river by ana-lysing the media, the former concentrating on the perspective of Helsinki and the latter on perceptions of the river in the upstream communities. The popular twentieth anniversary publication of the River Vantaa Water Protection Association (Kauppila, ed. 1983) presents 
During the nineteenth century, the city of Helsinki, a capital since 1809, developed into the most important Finnish city. It grew in size, population and industrial activity and strong investment in modern urban infrastructures began. While its number of inhabitants was still rather small compared to other European capitals, by the turn of the nineteenth century Helsinki was becoming 'a metropolis of modest proportions'. ${ }^{23}$ From a city centre perspective the River Vantaa was in the outskirts of the city. Its mouth is a shallow bay of the Gulf of Finland approximately six kilometres north of the city centre, which lies on a peninsula jutting out into the Baltic Sea. Settlements have grown along the river and its banks, especially in the southernmost part, have been the site of numerous small villages. ${ }^{24}$ The river has been utilised in several ways throughout its history, both for economic activity (e.g. mills, industries, ice production) and as a transportation route (rafting of logs, ice roads). Individual people have also utilised the river water in many ways, including laundering, taking water for saunas and watering their gardens. The small number of lakes in the drainage basin of the river Vantaa increases the importance of the river as a recreational waterfront environment for the local people, who are historically and culturally very attached to natural waterways. ${ }^{25}$ Recreation on the river (swimming, fishing, ice skating) and spending time on the riverbank have been popular and important to individual people living in the vicinity of the river. ${ }^{26}$ However, its history has been shaped most by its dual function as a recipient of wastewaters and as a source of fresh water.

\section{OVERLAPPING INFRASTRUCTURES: SHARED RIVER FUNCTIONS}

The early water supply system in Helsinki and the River Vantaa watershed area was based on very local water sources and they served the immediate neighbourhoods. Nearby residents collected their water in Helsinki from both centrally-located public wells and private wells amid housing blocks. In 1875 Helsinki had a total of 24 public and 336 private wells; however, they were partly in sub-standard condition. Authorities were especially alarmed by concerns about fire prevention and public health issues. Many of the wells were dry, or frozen during the winter; and, during a severe drought in 1875-1876,

an overview of the history of the river without accurate references. The history of the Water Works of Helsinki has been compiled by Lillja (1938), Erävuori (1976) and Herranen (2001), of which especially the latter has been valuable for this study. Schönach (2004 and 2007) has investigated the critical years of pollution incidents in the river water and the beginnings of intercommunal water protection efforts. Rajala (2013) has investigated the water supply management of the city of Vantaa, which is located in the river Vantaa drainage basin.

23. Bell and Hietala 2002, 134-137.

24. Kosonen and Rekola 1983, 14-15.

25. See, e.g., Raivo 2002, 93.

26. Schönach 2004, 21-22. 


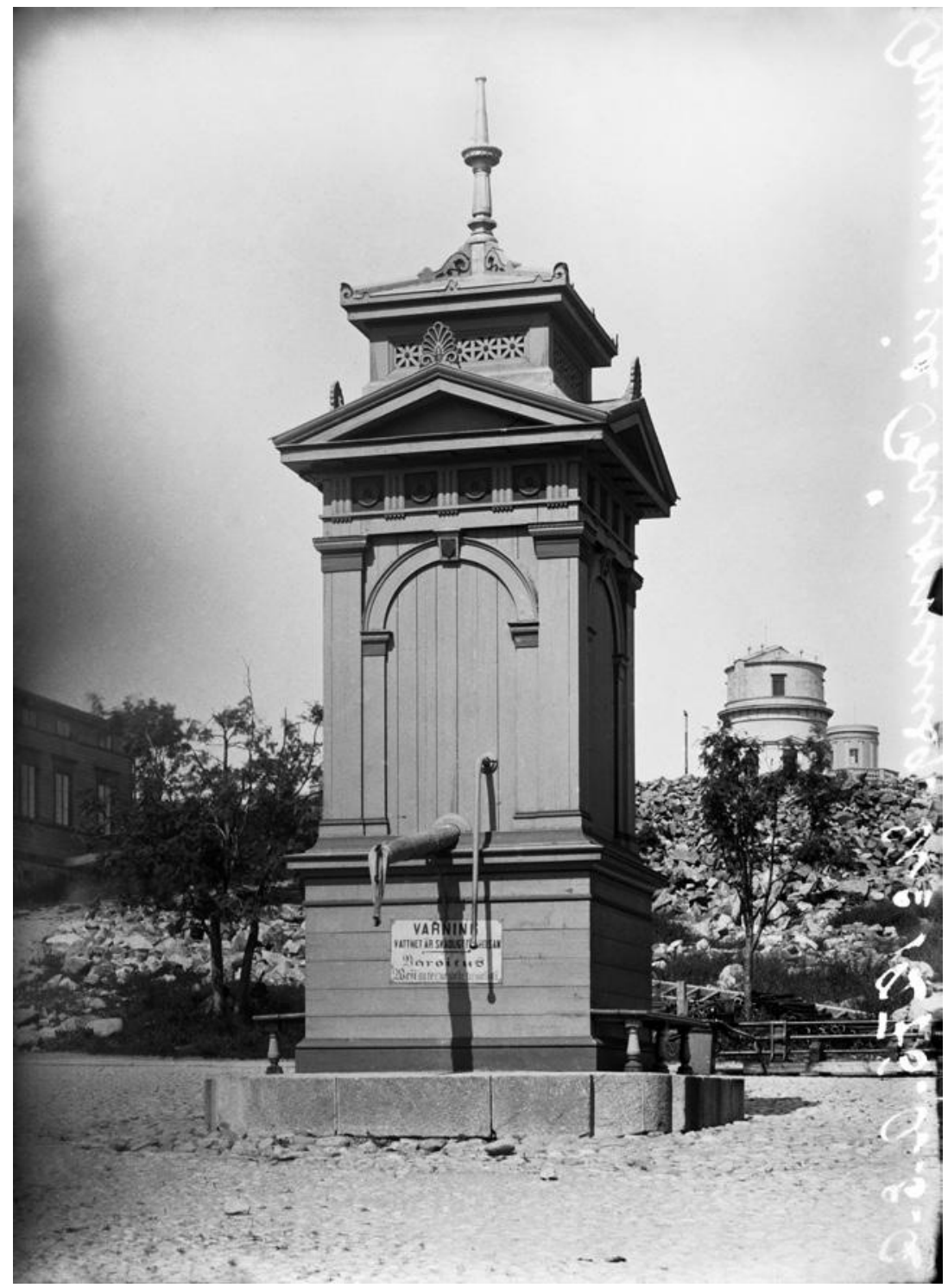

Figure 1. A public well in downtown Helsinki in the early 1900s. The sign underneath the tap says in Swedish and Finnish: 'Warning! The water is damaging to health'.

Photograph: A.E. Rosenbröijer, Helsinki City Museum, Photo Archive. 
well water had to be rationed. At the same time well water was increasingly poor tasting, the water was murky and inspections revealed serious health risks related to well water. It often was polluted by uncontrolled sewage inflow from latrines and manure from stables. (see Figure 1) Frequently occurring troubles with the abundance and purity of well water together with increasing urbanisation, population density and worrisome news about contagious diseases convinced the authorities about the need to shift the predominantly private water supply towards a municipally-organised system based on a reliable water source. $^{27}$

The decision-makers in Helsinki took a first step of expanding the hydro-graphic network for water supply of the capital in 1876 . They decided to start supplying central Helsinki with water from River Vantaa. It was extracted close to the river mouth, in the outskirts of the growing city. During the early years of water distribution, the Water Works officials praised the excellent qualities of the river water. It was considerably cleaner and better than well water and 'completely odourless and during warm weather periods one could leave the water standing for weeks without it going off ${ }^{28}$ The Helsinki Water Works soon began conducting research on the water quality of both filtered and un-treated river water on a regular basis. The muddy and humus-rich river water was purified first with filters and chemical treatment started in $1909 .{ }^{29}$

After it had become the cornerstone of the capital's water supply, the aim became also to secure its good quality legally. In 1882 the Governor banned pollution of the River Vantaa and its tributaries - an offence punishable with a fine of 25-100 Finnish Marks. The offence included activities that could harm the water purification process, like 'throwing carcasses or other wastes into the river and industrial activities' ${ }^{30}$ As a result, one tannery and a soap factory were ordered to be inspected; nevertheless, there is no evidence of any prosecutions.

Similarly to Helsinki, but roughly half a century later, the upstream com-munities faced the challenges of satisfactory water supply. The upstream villages had been dispersed and rather small rural population centres, but the first half of the twentieth century was marked by a large population increase. Three municipalities doubled and two even tripled their population within a few decades. ${ }^{31}$ Increased population density and gradual urbanisation brought

27. Fagerlund 1897; Waris 1973, 196-198; Carpelan 1998.

28. Lillja 1938, 170-171. Translation by the author.

29. Erävuori 1975. The construction work of the early network was completed by German company Neptun, but the water works were municipalised in 1876. The Helsinki Water Works were amalgamated with neighbouring communal water works, the regional waste management authority and environmental services in 2010 as the Helsinki Region Environmental Service Authority. For an overview of the development of water supply and sanitation in some other Finnish towns, see Juuti and Katko, 2005.

30. Fagerlund 1897, 47-48.

31. River Vantaa Water Protection Association (RVWPA)/Minutes of meetings/5 Jun 1958, $3 \S$. 
about new sanitary problems in the form of stagnant wastewater puddles and backyard privies that flooded and polluted wells. Here, however, the munici-palities could base the development of water supply networks on a more locally controllable resource, namely abundant groundwater resources. ${ }^{32}$

In consequence of the gradually advancing water supply system upstream, water consumption and amount of wastewater increased, while disposal re-lied on rather randomly dug and poorly maintained ditches. The residents and their representatives began to insist they needed a closed and controlled sanitary infrastructure in order to improve hygienic conditions in the urbanising communities. ${ }^{33}$ Sewage works were gradually started; however, for decades they competed for funding with several other targets of potential municipal expenditure, like welfare services and construction. They were often carried out as socially justified emergency-employment-work, i.e. state or municipal construction projects aimed at relieving seasonal unemployment. Hence, progress in the building of infrastructure was tied to the larger national economic situation. ${ }^{34}$

As for the sewage infrastructure, the upstream communities relied entirely on the water flow of the River Vantaa and its tributaries as they were the only natural watercourses north of Helsinki to receive wastewater. ${ }^{35}$ As soon as the Helsinki Water Works started daily bacteriological investigations of the river water in 1909, the presence of E. coli-bacteria was evident. The bacteria originated in human excrement and a clear increase in the amount of bacteria was already noticed between $1913-1935 .^{36}$ The upstream communities' decision-makers were predominantly engaged in securing wastewater flow from sites to the river, but were hardly interested in its fate further downstream, since the common understanding of the naturally occurring, self-purifying power of flowing water bodies prevailed. ${ }^{37}$

32. Ahtiainen and Tervonen 2002, 431. In Vantaa, however, the pipe-based water supply network has been constructed more slowly than, e.g., in Helsinki and even today some households in Vantaa are not connected to the municipal water supply network. The City of Vantaa started during the 1960 s to provide fresh water with tank trucks to remotely located households, see. Rajala 2013.

33. The issues were discussed many times, see, e.g., City of Vantaa Archive (CVA)/Municipal Council minutes/Ca2:8/29 May 1954, 15§; CVA/Municipal Executive Board minutes/Ca3:9/20 April 1955, 24§ and 30§; CVA/Municipal Executive Board minutes/Ca3:13/20 Jul 1959, 31 .

34. Hoffren and Penttilä 1979, 826; Rosenberg 2000, 138.

35. The sewage from most parts of Helsinki didn't affect the state of the river, since sewage both untreated and via treatment plants was directed into the coastal waters. Finland's first waste-water treatment plants were built in Helsinki and Lahti in 1910. For more, see Laakkonen 2001.

36. Lillja 1938, 174.

37. Katko 2005, 26-27; E.g. the city of Vantaa started to build small-scale settling wells to public buildings in the post- World War II years (e.g. CVA/Municipal Executive Board minutes/Ca3:8/16 June 1952, $61 \S$ and 16 March 1953, 35§) but a majority of sewage flowed entirely and very poorly treated in the river for many decades to come. 
The City of Helsinki had little legal ability to defend its fresh water re-source from upstream pollution. The effective Health Act of 1927 forbade the pollution of water by industry, but the wording was too general to give the downstream authorities any real tools to act. ${ }^{38}$ Municipal jurisdiction also stopped at the municipal border and in riverine cases downstream communities had no legal right to interfere with action upstream. However, upstream and downstream communities with very few prior political or legal connections were now closely connected through the riverine environment.

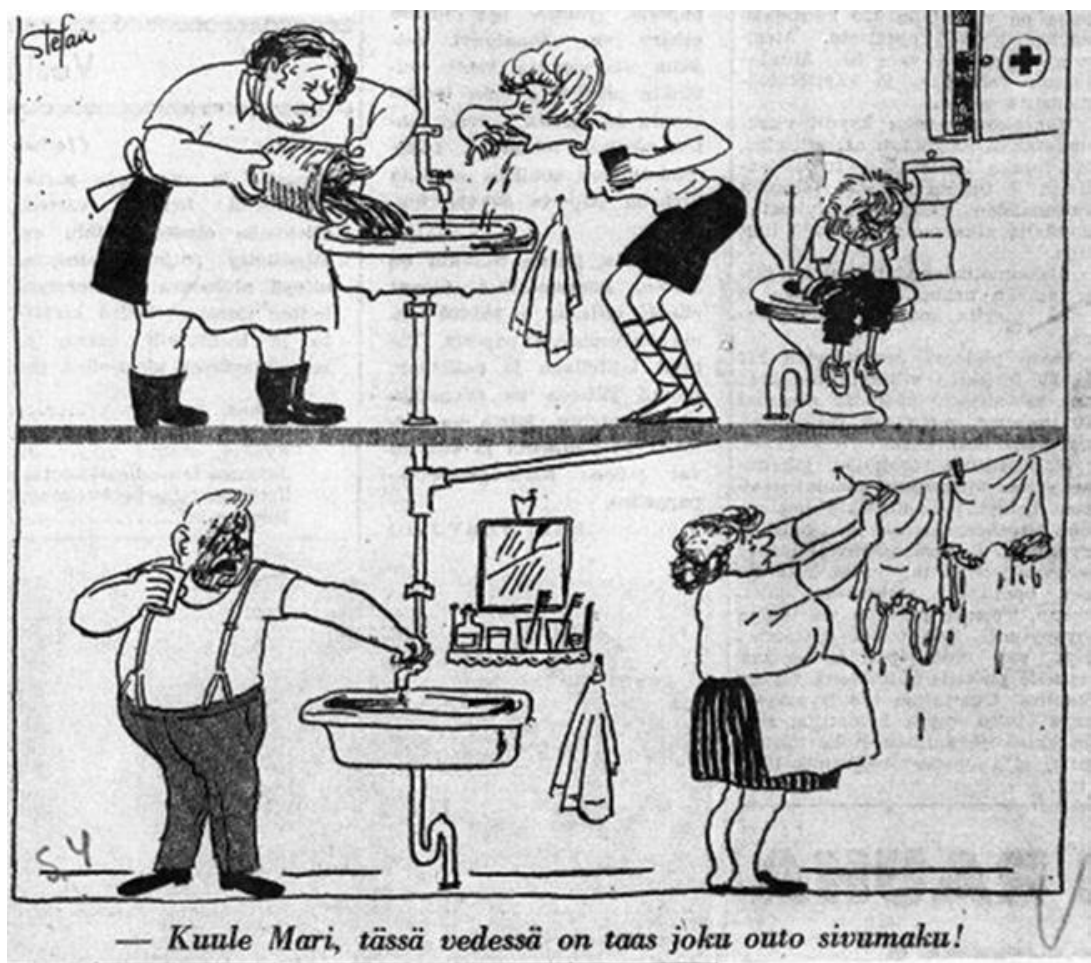

Fig 2. 'Listen Mary, this water has a strange after taste again' (Suomen Sosialidemokraatti, 15 Jul. 1967).

Wastewater infrastructure upstream and water supply infrastructure down-stream shared the River Vantaa as a core of their functioning. The cartoon shown in Figure 2 encapsulates this relationship. The two distinct infra-structural systems for water supply and wastewater were separately planned, managed and built; however, spatially and functionally they overlapped in the River Vantaa. 


\section{INFRASTRUCTURE FAILURE -CRISIS OF WATER SUPPLY}

Starting from the 1930s, Helsinki Water Works faced severe concerns about its ability to provide citizens with water sufficient in quantity and tolerable in quality. The city of Helsinki continued to grow steadily during the twentieth century. In 1946 large municipalities, mostly north of the city and along the River Vantaa, were annexed to Helsinki in order to strengthen urban growth. The city's land area grew over night more than five-fold and Helsinki got more than 50,000 new inhabitants. A period of intense city planning, construction of apartments and extension of infrastructural services began. Among others, water supply infrastructure was most pressingly needed in the new suburbs. ${ }^{39}$ Citizens were eager to connect to the modern urban convenience of the expanding water supply network. New modes of water consumption increased the per capita consumption of water from sixty litres a day at the turn of the century to nearly 300 litres in 1960. Figure 3 demonstrates the per capita increase in water use that, together with the general population increase and the expansion of the water supply network, resulted in a rapidly increasing demand for water.

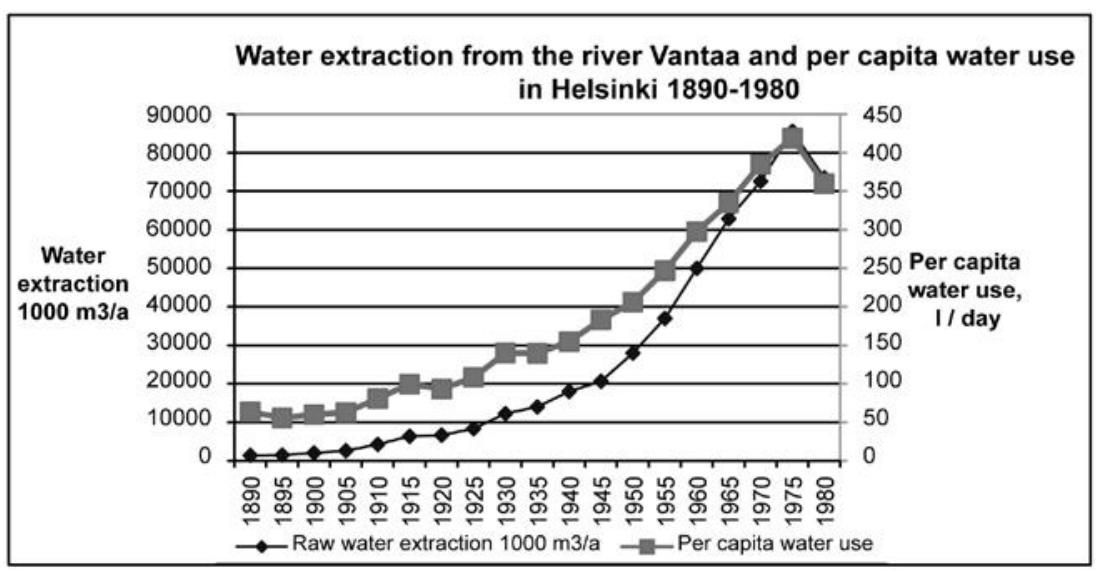

Figure 3. Number of consumers in water supply network and per capita water consumption in Helsinki 1890-1980. (Compiled from the Helsinki Water Works yearbooks)

The Water Works struggled to keep pace with the increasing demand for water. Future projections expected the demand for water to rise even faster, and extraction of fresh water was already nearing the river's modest natural 
flow. ${ }^{40}$ At the same time, the water purification capacity was approaching its limits. Consumption peaks exceeded the filtration capacity of the Water Works and citizens received suspiciously brown-coloured tap water. In the 1950s the public was advised to bath on less popular days, like Monday or Tuesday, instead of Thursday and Friday, to reduce consumption during peak times and ensure the adequate supply of clear water. ${ }^{41}$

The first plans to regulate the water level in upstream lakes date back to the 1930s and, after the war years, the regulation of two upstream lakes began as an emergency procedure. During the 1950s, the Water Works received permission to regulate a total of fve lakes upstream. The natural lakes were turned into storage basins for urban water needs and the engineers at the Water Works headquarters decided on the water surface levels. The natural flow of the River Vantaa was manipulated to meet the water needs of the capital and the water bodies in the watershed used to create a networked system of controlled resource transportation. In the language of the Water Works, the tributaries connecting these lake reservoirs were mere discharge channels. ${ }^{42}$ Along with the quantitative concerns, the repeated disturbing qualitative problems of the river water as a water supply resource concerned the authorities and the public.

Tap water in Helsinki had repeatedly an unpleasant smell, taste and appearance. The first indications of pollution in the river had already been detected in the 1930s, when, despite the purification process, the water tasted like it had come out of a 'plant pot'. ${ }^{43}$ Problems grew during the 1950 s, and descriptions of the foul water included remarks that it smelled like 'dried stockfish' and tasted of 'roof tar' and 'wet woollen stockings', a 'shingle-roof' and 'medicine'. ${ }^{44}$ Normal purification was no longer sufficient and occasionally the water's unpleasant smell and taste was even intensified during the purification process as it reacted with the chemicals used. Investigations revealed that communities and industries upstream polluted the river with an array of harmful substances and the river water contained problematic compounds such as phenols and their by-products, petroleum and turpentine. The quality of tap

40. Calculations about fresh water abundance became especially alarming when consider-ing the record low water levels in winter 1939-1940. HCA/Committees/Water Supply

Committee/K:246,1/Kirjeistö 1959, PM Oct. 1959, esp. App. 4a. Also newpapers reported frequently about water shortages, see e.g. Helsingin Ympäristölehti 26 Jul. 1946, 2; Suomen Sosialidemokraatti 28 Nov. 1953, 1-2; Hufvudstadsbladet 14 Oct. 1956, 11.

41. Ilta-Sanomat 13 Oct. 1956, 3; Hufvudstadsbladet 14 Oct. 1956, 11.

42. HCA/Committees/Water Supply Committee/K:246:1, Letters 1959, PM Oct. 1959, Appendix to letter from 28 Oct. 1959, 3 .

43. Tammela 1983, 66.

44. Uusi Suomi 9 Feb. 1954, 4; Ilta-Sanomat 3 Jan. 1958, 3; Helsingin Sanomat 4 Jan. 1958, 6; Hufvudstadsbladet 3 Jan. 1958, 1. 
water was becoming intolerable, and direct complaints from the public became more frequent and the media more critical. ${ }^{45}$

During the 1950s, as the chemical solutions to the problems used by the Water Works were no longer sufficient, they turned to more fundamental changes in the infrastructural system. The Water Works decided to build a new purification plant to increase purification capacity. It was located at Pitkäkoski, roughly eight kilometres north of the river mouth (see Map 1). During the preparatory phase, the Public Works Board objected to sacrificing a beautiful river bank area to infrastructural constructions, but the Water Works insisted on the location: the southernmost tributary of the river, Keravanjoki, was recognised as the most harmful source of the pollutants spoiling the river water, and the location of the new purification plant north of the confluence of Keravanjoki to the main river enabled water extraction before the influence of the polluted Keravanjoki. ${ }^{46}$ The new purification plant relieved capacity problems but, however, didn't solve the persistent taste problems present in tap water.

Representatives of the City Council, who were also individual consumers of the water, repeatedly urged for measures to improve the water provided to the city. ${ }^{47}$ Finally, the issue of the capital's water became so critical that the National Bureau of Investigation started to examine what facility was polluting the river with phenols. The investigation revealed that at least 26 industrial facilities used phenols or related compounds in their processes and ran their wastewater, mostly very poorly treated, if at all, into the river or ditches leading to it. ${ }^{48}$ However, very little resulted from either the local or national enquiries, particularly because in the phenol case no one offender was solely responsible. Since the episodes were of short duration, the Water Works' reactive measures were seen as sufficient - the only new measure the City Council considered necessary was to examine the legal possibilities for the city of Helsinki to influence decision making on activities causing pollution in upstream communities. $^{49}$

The central motivation for both the political reactions and the proposed measure was to push for better drinking water. This reveals that pollution of the river was viewed as merely a resource concern of the Water Works and the service it delivered. The riverine environment as such did not make the headlines. However, after years of occasional problems with tap water quality and public complaints about the poor taste and smell, the severest crisis was still ahead.

45. Helsinki Water Works Archive/ Water Inspection Office/ Water Quality Reports 1960-1963; Uusi Suomi 9 Feb. 1954, 2, 4; Rahikainen 2001, 211 ff.

46. HCA/City Council minutes/19 Jun 1957, 564§; Herranen 2001, 105.

47. HCA/Helsinki City Council minutes/20 Feb. 1957, 221§; 22 Jan. 1958, 75§; 12 Feb.1958, $165 \S$.

48. Province Archive of the Region Uusimaa/Memorandum 3895/B37/58, received 7 Feb. 1958 from the Deputy Attorney General,

49. HCA/City Board minutes/20 Mar. 1958, $915 \S$. 
In Helsinki the summer of 1959 was very warm and dry, with temperatures well above normal and precipitation less than average. ${ }^{50}$ Additionally, the weather in August had been very still, so turbulence in the river water had been very low. Increased algae production in the river had already been observed earlier that summer, but on 22 August 1959 the river suddenly turned green as a lawn. A strong smell of mould was detected at the water purification plant, and the next day it spread all over the city via the water supply network. ${ }^{51}$ It was found that the taste of mould was caused by a sudden increase in the existence of the cyanobacteria Anabaena circinalis, which formed an instantaneous, algae-like bloom in the river. As the mouldy smelling water was used throughout the city, for drinking, preparing food, laundry and cleaning the streets, soon the entire city exuded a smell of mould. Every citizen could concretely sense the decay of the river. The incident revealed the dynamic relationship between the river, its natural processes and the sanitary infrastructures of the 'involuntary neighbours' along the river. The water supply infrastructure was no longer providing its service hidden in the background, as is typical for infrastructural networks. ${ }^{52}$ The foul water intruded into people's homes and lives, thus revealing how vulnerable and prone to failure the infrastructure was. A cause of anxiety normally absent from everyday life was dogging the city. ${ }^{53}$

The public complained fiercely about the incident, and media criticism was relentless. One newspaper even wrote that one's 'bloody teeth cannot be brushed with this tap water, ${ }^{54}$ The failings in the infrastructure even led to the emergence of alternative water supplies during the worst periods. Even though they never seriously competed with tap water on a large scale, sales of bottled mineral water, whose use has been extremely uncommon in Finland until very recent times, and other forms of 'imported' water grew. The idea of infra-structure networks being natural monopolies was symbolically challenged, as the water crisis pushed people to look for alternatives. ${ }^{55}$ Workers commuting to Helsinki from outside the water supply network brought clean water from home for coffee or other purposes during the working day. A new phenome-non on the streets of Helsinki was the sight of people carrying jugs and other containers. ${ }^{56}$ Some entrepreneurs saw the water crisis a potential source of new business or marketing. One newspaper reported on a brewery that had started

50. Finnish annual weather statistics.

51. Tammela 1959, see also e.g. Hufvudstadsbladet 25 Aug. 1959; Suomen Sosialidemokraatti 25 Aug. 1959.

52. Cf. Graham and Marvin, 2001, 30.

53. Cf. Kaika 2005, 60-61.

54. Nya Pressen 1 Sep. 1959.

55. Graham and Marvin 2001, 79.

56. Helsingin Sanomat 4 Sep. 1959, 4. 
to deliver free mineral water to a newly established cancer hospital and its patients. $^{57}$

This unprecedented situation triggered frantic activity at the Water Works to solve the problem. The purification process was modified to secure physically, chemically and bacteriologically satisfactory water, but the bad smell and taste persisted. Drawing on experiences from London, it was decided that the elimination of the algae would be attempted by using an emergency procedure with a copper sulphate solution. Its toxicity provoked disputes among personnel at the Water Works, but public pressure to improve the water quickly outweighed objections to the measure. The solution was hosed into the river approximately eight kilometres upstream of the purification plant of Pitkäkoski. In this way the poison was allowed to take effect in the river water before it reached the intake pipe and entered the purification process. The measure succeeded and the algae was destroyed; however, all the water between the injection point and the point of water withdrawal had to flow with its sluggish pace, before the tap water would once again have a neutral taste. A taste of mould was present in the tap water for nearly two long weeks. ${ }^{58}$

Furthermore, even though chemical intervention relatively soon relieved the acute crisis, the ultimate reason for the incident remained. An excess of nutrients originating in untreated sewage discharges and, to some extent, run-offs from agricultural land had eutrophicated the water content in the river to levels favouring the excessive growth of algae. ${ }^{59}$ The long-term accumulation of discharges into the river from human activity had changed the river ecosystem and rendering it less suitable for human usage.

The algae-crisis had several direct and indirect consequences for the River Vantaa, and the socio-political and infrastructural context it was a part of. At the national level, the crisis influenced the preparation of the new Water Act which was taking place at the time. The law was revised to allow the use of chemicals to prevent algae-induced disturbances. ${ }^{60}$ As a consequence, the use of copper sulphate as a preventive measure became the norm in the drainage basin in cases when environmental conditions favoured cyanobacterial blooms. However, this resulted in high copper concentrations in the river water, which later considerably exceeded the national limits set for drinking water. ${ }^{61}$ The algae-crisis also triggered an alteration in communal investment priorities, since,

57. Suomen Sosialidemokraatti 3 Sep. 1959, 9; Hufvudstadsbladet 3 Sep. 1959, 4.

58. Schönach 2004.

59. The use of artificial fertilisers and the intensification of agricultural production clearly in-creased in Finland after World War Two, and in Southern Finland more than elsewhere in the country. An excess of nutrients in over-fertilised fields in the drainage area increased leakage to surface waters, but in 1959 this had not yet been the case for very long. Thus, it is difficult to determine the share due to agricultural run-off (Vantaanjoen ja Helsingin seudun vesiensuojeluyhdistys 1965, 25; Antikainen et al 2008, 174).

60. Water Act 264/1961; Herranen 2001, 109.

61. HCA/Helsinki Water Works Annual Reports; Rahikainen 2001, 217. 
prior to this, the improvements in water supply and wastewater infrastructure had long been neglected in favour of other infrastructures, e.g. the electricity infrastructure. ${ }^{62}$ This became evident when the Helsinki Water Works started to widen the geographical perspective of its operations.

\section{TERRITORIAL EXPANSION OF THE HYDROLOGICAL REGIME}

The constant difficulties of the Helsinki Water Works in providing high-quality water to consumers, culminated in the algae-catastrophe of 1959. The crisis triggered investigations into its cause, and political and public demands for a prompt reaction to the unacceptable state of the river gained new and, finally, irresistible momentum.

The City Board, which, one year earlier, had been reluctant to take any decisive measures, now acted immediately, and a Water Supply Committee was appointed within a week of the start of the crisis. The task was to plan how the water supply of the capital could be organised in a satisfactory way in the future. ${ }^{63}$ The Committee soon raised the question of alternative water sources for the capital and supported the Water Works' extensive and costly plans to lessen dependence on the river Vantaa. ${ }^{64}$

The plans centred on increasing the available water volume to allow more effective dilution of pollution, enhance self-purification and mitigate sudden qualitative changes in the river water. Additionally, it would serve to meet the demands of increasing water consumption. Firstly, water was to be channelled from Lake Hiidenvesi, a lake northwest of the River Vantaa. However, the rerouting of water from Lake Hiidenvesi into the river was delayed until 1969 due to local opposition and hence a prolonged permit procedure in the Water Court. ${ }^{65}$ Secondly, a reservoir was to be built in Silvola, close to the new purification plant at Pitkäkoski (see Map 1). The construction plan of the reservoir was approved by the City Council in March 1960, only six months after the algae-crisis. It was seen as indispensable both from a quantitative and qualitative perspective. The advantages of building a reservoir included improved quantitative regulation of the downstream water flow and qualitative improvements through retention time in the lake with artificial water circulation to enhance the self-purification processes of the body of water. Monitoring and chemical treatment of the raw water would also be easier in the reservoir.

62. Herranen 2001, 122.

63. HCA/City Board minutes/10 Sep. 1959, 2347§. In March the previous year the City Board denied the need for a commission to deal with the water issues, see HCA/City Board minutes/12 Mar. 263§ and Appendices.

64. HCA/Committees/Water Supply Committee/K:246:1 and K:246:2.

65. Herranen 2001, 116. 
The plan was praised as a long-awaited and important step towards a better water supply. ${ }^{66}$ Neither did the location of the reservoir raise any serious objections. Three farmhouses were expropriated, but otherwise the surrounding area of forest and field was seen as particularly suitable, since it was in a natural depression that allowed the construction of the lake to be a 'completion of nature's own work'. ${ }^{67}$ The reservoir was ready for incorporation into the water supply network in May 1962. The reservoir, which covers an area of 0, 47 square kilometres, holds five million cubic metres of water.

The reservoir has never been available to the public for recreational purposes, for it is a fenced and guarded body of water. The reservoir is far from the Finnish image of a lake but, as a rule, it is still known in Finnish as an 'artificial lake' (tekojärvi) rather than a reservoir. The Silvola reservoir is the largest visible surface construction created for the infrastructural needs of the city of Helsinki.

While the water infrastructure visibly stretched to cover new land area, it also expanded under the surface. A third immediate construction work following the years of water crisis in the capital was a $7.6 \mathrm{~km}$ tunnel between the purification plants at Pitkäkoski and the river mouth. The channel drilled twenty metres deep into the solid rock enabled the concentration of all water extraction upstream, where pollution levels were less hazardous. ${ }^{68}$ The new components incorporated in the infrastructural system promoted enhanced management and manipulation of the water. The hydrological network around the River Vantaa grew denser and stretched further and deeper into the region.

Although offering some relief to the pressing problems of water supply, the Helsinki Water Works saw these measures only as partial and temporary solutions. The Water Supply Committee and national authorities, heavily influenced by the leaders of the Helsinki Water Works, prepared a general plan to address the capital's pressing water needs and pursued for a 'final solution'. ${ }^{69}$ Documents of the Water Supply Committee reveal that eyes had already been turned to further watersheds with more generous water bodies. ${ }^{70}$ - They subsequently recommended Lake Päijänne as the future fresh water source for the capital.

Lake Päijänne is the second largest lake in Finland $\left(1,080 \mathrm{~km}^{2}\right)$ and its southern shore is located approximately $120 \mathrm{~km}$ north of Helsinki. Its water, especially in the south of the lake was, and still is, very clean, and the lake's massive volume of water would allow substantial water extraction without affecting the interest of other lake users. The emerging probability of Lake

66. HCA/City Council minutes/23 Mar. 1960, $236 \S$.

67. HCA/City Council minutes/23 Mar. 1960, $236 \S$ Representative Loimaranta.

68. HCA/City Council Printed Documents/Decisions 1963, 29 May 1963, N:o 40.

69. Helsingin Sanomat 9 May 1982, 29.

70. HCA/Committees/Water Supply Committee/K:246:1, Kirjeistö 1959, Letter to the City Board 25 Nov. 1959. 
Päijänne's integration into the water infrastructure of the capital had profound environmental consequences, for now the incentive to protect Lake Päijänne from further pollution was great. ${ }^{71}$ Consequently, authorities imposed tight regulations for wastewater discharges to avoid pollution of the lake. The city of Helsinki also co-financed some of the new wastewater treatment facilities on the shores of the lake. Reino Kalliola, a leading figure and pioneer of Finnish conservation, stated that harnessing Lake Päijänne as a water resource for the capital was the best guarantee there could be for protection of its environment. ${ }^{72}$

The construction of an aqueduct from Lake Päijänne began in 1972. After completion of the first construction phase in 1979, the tunnel reached the northernmost part of the river Vantaa, and water from Lake Päijänne was run into the natural riverbed, thus increasing the water volume and enhancing riverine self-purification processes. In the final phase the $120-\mathrm{km}$-long tunnel reached the Pitkäkoski water purification plant directly and lake water from Lake Päijänne took over as the exclusive source of raw water for the water sup-ply network in $1982 .^{73}$ The aqueduct replaced the River Vantaa as the 'Stream of Life' ${ }^{74}$ of the capital.

Urban dependencies on water bodies had extended to more peripheral territories than ever before and the thirsty capital had imposed 'hydraulic imperialism' over the drainage basin and beyond. ${ }^{75}$ Large-scale engineering projects had taken over new land area and infrastructural facilities distended both on and under the surface. The new components of the infrastructure included artificial channelling and storage of water in both semi-natural and man-made constructs. Above all, the spatial range of the infrastructure network enlarged to tap into new and abundant sources of clean raw water resources and hence expanded the capital's hydrological territory.

\section{RECOVERING RIVER}

While the political and administrative leaders put most of their effort in the inclusion of distant water bodies into the water supply infrastructure of the capital, initiatives to enhance the environmental protection of the River Vantaa

71. HCA/Committees/Water Supply Committee/K:246:1, Kirjeistö 1964, Tentative PM, 'Päijännesuunnitelma', 12.

72. Helsingin Sanomat 16 Mar. 1969; Herranen 2001, 187-191.

73. The Päijänne aqueduct is the second longest continuous rock tunnel in the world, surpassed only by the Delaware Aqueduct, serving New York City with water. The River Vantaa has remained a reserve water source. Most recently the river Vantaa was used as a water source for eight months in 2008 during renovation work on the Päijänne tunnel. The water from Lake Päijänne serves more than one million people in the capital region now that water supply services have been centralised as a result of region-wide co-operation.

74. Helsingin Sanomat 9 May 1982, 29.

75. Colten 2012, 201. 
advanced concurrently. Previously, upstream communities had been reluctant to invest in wastewater purification and for decades treatment capacity had failed to keep pace with the expansion of sewerage systems and waste water directed to the river. ${ }^{76}$

This had been for both economic and attitudinal reasons. Because of the scattered locations of the separate urbanising villages, the construction of centralised wastewater treatment was difficult and expensive, as each of the small villages would have needed its own treatment plant. ${ }^{77}$ The upstream communities were reluctance to prioritise sewage treatment investments because they viewed the river as a natural sewage channel, maintained wishful thinking about the dilutive power of the riverine environment and struggled with the common property dilemma of watercourses. Water protection efforts were not seen to be profitable, since 'the neighbour will anyhow spoil the water and negate all our efforts', as the national Water Protection Committee expressed it in $1958 .^{78}$ Leaders of the upstream communities commented that the city of Helsinki would be the greatest beneficiary of investments in river protection, and they could not see a lucrative enough reward. ${ }^{79}$

However, River Vantaa protection gained momentum from the 1960s on-wards, after the algae crisis. The protection of the river from further pollution was pursued in 1963 by the foundation of the River Vantaa Water Protection Association. At the same time, a new Water Act, which came into force in 1962, institutionalised the concept of 'water protection' and gradually challenged the view of water self- purification as the major factor in water protection. The law forced communities to start investing in wastewater treatment and, even though the earliest sewers in Finland had been built in the nineteenth century, the largest expansion of sanitation services took place between the late $1950 \mathrm{~s}$ and the $1980 \mathrm{~s}^{80}$

Both the new Water Act and the River Vantaa Water Protection Association initiated cooperation between municipalities to enhance purification of up-stream sewage. Successful inter-communal water protection efforts resulted

76. Katko 2005, 26-27; Rosenberg 2000, 138. A factory complex producing yeast, vinegar and spirits in Rajamäki tested an activated sludge plant for wastewater purification as early as 1924 and a biological treatment plant in 1940 (Kauppila 1988, 289). A hospital in the watershed started biological purification in 1938 and three municipal plants were built in the 1950s. In general wastewater purification became more common in the drainage basin starting in the 1960s (Jokinen 1983, 50-51).

77. Vantaanjoen ja Helsingin seudun vesiensuojeluyhdistys 1967, 27-31.

78. Vesistönsuojelukomitea 1958,132 . The common property dilemma originates from Garrett Hardin's 'Tragedy of the Commons' (1968).

79. RVWPA/Minutes of meetings/26 Feb. 1963, $4 \S$.

80. Katko 2005, 26-27. The recycling of human waste for agricultural production was gradually vanishing in Finland, as in most western countries; with the advance of urbanisation and modern living standards, most sewage was now flushed into watercourses. The question of the use of urban sewage as fertiliser has been studied in the Finnish context by Laakkonen 2001 and Nygård 2004. 
in wastewaters being increasingly drained into centralised purification plants and, as a final stage, discharged into coastal areas, instead of the river. This was the single most important set of measures that contributed to the gradual, but considerable improvement to the water quality of the River Vantaa. ${ }^{81}$

Newspaper features about the river became more optimistic in tone and the environmental protection of the river gained momentum among the public too. ${ }^{82}$ Throughout its history, the River Vantaa has been an important recreational environment for local people, especially because there is a dearth of other bodies of water in the region. Nevertheless, its function as a sewer and resource for water supply had far outweighed other, more diverse interests. Being freed from its role as a fresh water resource marked a turning point in the history of the river. This was highlighted in the large number of column inches in newspapers and magazines devoted to reflections of the river's past and visions of the approaching new era. ${ }^{83}$ The recreational value of the river was emphasised in an unprecedented way; instead of a predominant sewer and fresh water resource, it was becoming a 'recreational artery' running through the capital region. ${ }^{84}$

The development of water supply and wastewater infrastructures in the region of the River Vantaa watershed, southern Finland, follows a century-long path of spatial expansion and densifying networks. In Helsinki, a very local, early fresh water system based on private and public wells was replaced by a pipe-based transportation system of river water that allowed a more distant source of water and a wider area to be covered by water supply. Because the river was used by upstream communities at the same time, as the main dis-charge channel and transportation medium for untreated or poorly treated waste water, River Vantaa became a crucial node of these two distinct and overlap-ping infrastructures. This dual function altered the riverine environment and river water quality. The environmental degradation of the river Vantaa was a process that involved complex societal developments in localities along the river and the natural characteristics of the river. In particular, the Water Works of the city of Helsinki struggled, with the degrading river water, to fulfil, qualitatively and quantitatively, the fresh water needs of the growing city.

81. Ahtiainen and Tervonen 2002, 434-435; Schönach 2007, 31-33.

82. Helsingin Sanomat 24 Apr. 1974; Uusi Suomi 24 Apr. 1974; Uusi Suomi 17 Mar. 1975, 3; Hufvudstadsbladet 23 May 1975, 1, 16; Uusi Suomi 24 Aug. 1978, 1,6.

83. Helsinki-Lehti 17 Apr. 1975; Uusi Suomi 20 Feb. 1979; Alue-Uutiset 'River Vantaa yesterday and today'-series 5 Apr. 1979, 12 Apr. 1979, 28 Apr. 1979; Kansan Uutiset 'Life along the river'-series 11 Jul. 1979, 19 Jul. 1979; Pääkaupunkiseutu 4 Sep. 1980; Uusi Suomi 22 Nov. 1981; Kansan Uutiset 8 Mar. 1982; Ilta-Sanomat 20 May 1982. Translations by the author.

84. The phrase 'recreational artery' is borrowed from Helsingin kaupunki, johtajistotoimikunta (1988). A similar development of river degradation because of its excessive use for infra-structural or, e.g., industrial functions being converted into rivers being 're-gained' for the public via improved accessibility and recreational value has been presented, e.g., by Collins, Muller and Tarr (2008) and in the various cases in Kibel (ed.) 2007. 
The process of securing Helsinki drinking water can be seen as a continuum of an expansion of the capital's hydrological territory, both above and under the surface. Measures included the introduction of new water purification methods, construction of new water intake plants in more remote locations to avoid the impact of polluted tributaries, regulation of the upstream lakes and construction of an artificial reservoir for water storage, and, finally, connecting water resources of neighbouring watersheds via extensive channels to the water supply infrastructure. After a century of intensive use as water sup-ply infrastructure, the River Vantaa and its watershed were spatially bypassed by even larger engineered constructions to control the capital's hydrological network. In 1982, an aqueduct from Lake Päijänne replaced the River Vantaa as the primary fresh water source of the capital region in Finland. Some waste-water from upstream municipalities is still being discharged into the river; however, due to inter-communal collaboration in wastewater management since the 1960s, the environmental quality of the River Vantaa has improved substantially. Being decoupled from the expansionist development of sanitary infrastructure, the River Vantaa is now, after years of degradation, again available to more local uses.

\section{REFERENCES}

\section{Archival material}

City of Vantaa Archives (CVA), Vantaa

- Municipal Executive Board, Series Ca (Minutes of Meetings)

Helsinki City Archives (HCA), Helsinki

- Helsinki City Board for Technical Utilities, Series Ca (Minutes of Meetings) - Helsinki

City Council, Series Ca (Minutes of Meetings)

- Helsinki City Board, Series Ca (Minutes of Meetings)

- Helsinki City Board, Series Cb (Annexes to Minutes of Meetings)

- Helsinki Water Works, Annual Reports

- Water Supply Committee (Vesihuoltotoimikunta), 1959-1964, K:246:1 and K:246:2

Helsinki City Museum (HCM), Helsinki

- Photo Archive

Helsinki Water Works Archive (HWWA), Pitkäkoski, Helsinki

- Water Investigation Offce, Water Quality Reports 1960-1963

Archive of the Provincial Government of the Region Uusimaa, Hämeenlinna

- Memorandum 3895/B37/58, received 7 Feb. 1958 from the Deputy Attorney General, Series Ea:1317, Uudenmaan lääninhallituksen yhteisarkisto I.

River Vantaa Water Protection Association (RVWPA), Helsinki

- Minutes of Meetings 


\section{Literature}

Ahtiainen, Pekka and Jukka Tervonen. 2002. Vantaan historia 1946-1977: kasvua, yhteistyötä, hyvinvointia. Vantaan kaupunki: Vantaa.

Antikainen, Riina, Reija Haapanen, Riita Lemola, Jouni I. Nousiainen and Seppo

Rekolainen. 2008. 'Nitrogen and Phosphorus Flows in the Finnish Agricultural and Forest Sectors, 1910-2000'. Water Air and Soil Pollution 194: 163-177.

Bakker, Karen. 2010. Privatizing Water: Governance Failure and the World's Urban Water Crisis. Cornell University Press: Ithaca and London.

Barles, Sabine. 2007. 'Urban Metabolism and River Systems: An Historical Perspective - Paris and the Seine 1790-1970'. Hydrology and Earth System Sciences 11: 1757-1769.

Barles, Sabine. 2013. 'The Seine as a Parisian River: its Imprint, its Ascendancy and its Dependencies in the Late 19th and 20th Centuries'. Paper presented at a workshop 'Rivers, Cities, Historical Interactions', Rachel Carson Center, Munich, Feb. 2013.

Bell, Marjatta and Marjatta Hietala. 2002. Helsinki. The Innovative City. Historical Perspectives. Helsinki: Finnish Literature Society \& City of Helsinki Urban Facts.

Carpelan, Anna. 1998. Yleiset kaivot Helsingissä 1800-luvulla. Helsingin kaupunginmuseon tutkimuksia ja raportteja 1/1998. Helsingin kaupunginmuseo: Helsinki.

Carse, Ashley. 2012. 'Nature as Infrastructure: Making and Managing the Panama Canal Watershed'. Social Studies of Science 42(4): 539-563.

Castonguay, Stéphane and Matthew Evenden (eds). 2012. Urban Rivers: Remaking Rivers, Cities, and Space in Europe and North America. Pittsburgh: University of Pittsburgh Press.

Collins, Timothy M., Edward K. Muller and Joel A. Tarr. 2008. 'Pittsburgh's Three Rivers: From Industrial Infrastructure to Environmental Asset'. In Christof Mauch and Thomas Zeller (eds). Rivers in History. Perspectives on Waterways in Europe and North America. pp. 41-62. Pittsburgh: University of Pittsburgh Press.

Colten, Craig, E. 2012. 'Fluid Geographics: Urbanizing River Basins'. In Stéphane Castonguay and Matthew Evenden (eds). Urban Rivers: Remaking Rivers, Cities, and Space in Europe and North America. pp. 201-218. Pittsburgh: University of Pittsburgh Press.

Cronon, William. 1991. Nature's Metropolis. New York: W.W. Norton \& Company.

Dagenais, Michèle. 2011. 'At the Source of New Urbanity: Water Networks and Power Relations in the Second Half of the Nineteenth Century'. In Stéphane Castonguay and Matthew Evenden (eds). Urban Rivers: Remaking Rivers, Cities, and Space in Europe and North America. pp. 101-114. Pittsburgh: University of Pittsburgh Press. 
Dagenais, Michèle. 2012. 'The Rivière des Prairies: More than Montreal's Backyard?' In Stéphane Castonguay and Matthew Evenden (eds). Urban Rivers: Remaking Rivers, Cities, and Space in Europe and North America. pp. 75-92. Pittsburgh: University of Pittsburgh Press.

Doyle, Martin, W. and David G. Havick. 2009. 'Infrastructure and the Environment'. Annual Review of Environment and Resources 34: 349-373.

Erävuori, Jukka. 1975. 100 vuotta vesilaitostoimintaa Helsingissä. Julkaisuja No 28. Helsinki: Helsingin kaupunki.

Fagerlund, L.W. 1897. Helsingfors stads vattenledning och dess vatten. Hygienisk studie. Helsingfors: Helsingfors centraltryckeri.

Finnish annual weather statistics. http://ilmatieteenlaitos.f/vuositilastot (Accessed 12 Aug. 2013).

Goubert, Jean-Pierre. 1988. 'The Development of Water and Sewerage Systems in France, 1850-1950'. In Joel A. Tarr and Gabriel Dupuy (eds). Technology and the Rise of the Networked City in Europe and America. pp. 116-136. Philadelphia: Temple University Press.

Goubert, Jean-Pierre. 1989. The Conquest of Water: the Advent of Health in the Industrial Age. Translated from French original La conquète de l'eau (pub. 1986). Cambridge: Polity Press.

Graham, Stephen and Simon Marvin. 2001. Splintering Urbanism. Networked Infrastructures, Technological Mobilities and the Urban Condition. London and New York: Routledge.

Guillerme, André. 1988. 'The Genesis of Water Supply, Distribution and Sewerage Systems in France, 1800-1850'. In Joel A. Tarr and Gabriel Dupuy (eds).

Technology and the Rise of the Networked City in Europe and America. pp. 91-115. Philadelphia: Temple University Press.

Hardin, Garrett. 1968. 'The Tragedy of the Commons'. Science, 162: 1243-1248.

Helsingin kaupunki, johtajistotoimikunta 1988. Vantaanjoki - pääkaupungin kehdosta virkistyksen valtasuoneksi : toimenpideohjelma (1987-88) 1989-1993.(Working group report) Helsinki: Helsingin kaupunki.

Herranen, Timo. 1997. 'Kaupunkisuunnittelu ja asuminen'. In Oiva Turpeinen, Timo Herranen Timo and Kai Hoffman (eds). Helsingin historia vuodesta 1945. pp. 121233. Helsinki: City of Helsinki.

Herranen, Timo. 2001. Vettä ja elämää. Helsingin vesihuollon historia 1876-2001. Helsinki: Helsingin vesi.

Hoffren, Jouko and Kalevi Penttilä. 1979. Riihimäen historia I. Riihimäki: Riihimäen kaupunki.

Hughes, Thomas P. 1987. 'The Evolution of Large Technological Systems'. In Wiebe E. Bijker, Thomas P. Hughes and Trevor J. Pinch. The Social Construction of Technological Systems. pp. 51-82. First MIT Press paperback edition, 1989, Cambridge: MIT Press.

Jokinen, Olli. 1983. 'Vesistön esittely'. In Olli Kauppila (ed.) Vantaanjoki. Vantaanjoen ja Helsingin seudun vesiensuojeluyhdistyksen 20-vuotisjuhlajulkaisu. pp. 34-64. Helsinki: VHVSY.

Joyce, Patrick. 2003. The Rule of Freedom: Liberalism and the Modern City. London: Verso 
Juuti, Petri and Tapio Katko. 2005. 'Finland'. In Petri Juuti and Tapio Katko (eds).

Water, Time and European Cities. History Matters for the Futures. pp. 60-63.

Tampere: Tampere University Press. Accessed 20 Jun. 2013 http://www.sewerhis-

tory.org/articles/whregion/finland/european_cities.pdf.

Kaika, Maria. 2005. City of Flows: Modernity, Nature and the City. New York:

Routledge.

Katko, Tapio. 1997. Water! Evolution of Water Supply and Sanitation in Finland from the Mid-1800s to 2000. Helsinki: Finnish Water and Waste Water Works Association.

Katko, Tapio. 2005. 'Long-Term Development of Water and Sewage Services in Finland'. In Petri Juuti and Tapio Katko (eds.) From a Few to All. Long-Term Development of Water and Environmental Services in Finland. pp. 7-16. Tampere: Tampere University Press. Accessed 20 Aug. 2013. http://dspace.cc.tut.f/dpub/bitstream/handle/123456789/19324/juuti_katko_from_a_few_to_all.pdf?sequence=1

Kauppila, Olli (ed.) 1983. Vantaanjoki. Vantaanjoen ja Helsingin seudun vesiensuojeluyhdistyksen 20-vuotisjuhlajulkaisu. Helsinki: VHVSY.

Kauppila, Olli, 1988. Rajamäen tehtaat 1888-1988: 100-vuotisjuhlakirja. Helsinki: Painokaari.

Kibel, Paul Stanton (ed.) 2007. Rivertown: Rethinking Urban Rivers. Cambridge: MIT Press.

Kinnersley, David. 1988. Troubled Water: Rivers, Politics and Pollution. London: Hilary Shipman Ltd.

Kosonen, Mauno and Lasse Rekola. 1983. 'Vantaajoen vesistön käyttöhistoria'. In Olli Kauppila (ed.) Vantaanjoki. Vantaanjoen ja Helsingin seudun vesiensuojeluyhdistyksen 20-vuotisjuhlajulkaisu. pp. 9-33. Helsinki: VHVSY.

Laakkonen, Simo. 2001. Vesiensuojelun synty. Helsingin ja sen merialueen ympäristöhistoriaa 1878-1928. Helsinki: Gaudeamus.

Leino-Kaukiainen, Pirkko. 1999. 'Vesistöistä viemäreiksi. Vesiensuojelu Suomessa 1945-1970'. In Simo Laakkonen, Sari Laurila and Marjatta Rahikainen (eds). Harmaat aallot. Ympäristönsuojelun tulo Suomeen. Historiallinen arkisto; 113. pp. 33- 68. Helsinki: Suomen Historiallinen Seura.

Lillja, John L.W. 1938. Helsingin kaupungin vesijohtolaitos. Helsinki: Otava.

Luckin, Bill. 2001. 'Pollution in the City'. In Martin Daunton (ed.) Cambridge

Urban History of Britain. Volume 3, 1849-1950. pp. 207-228. Cambridge :

Cambridge University Press, Online. Accessed 13 Feb. 2013, doi: 10.1017/ CHOL9780521417075.008.

Mauch, Christof and Thomas Zeller (eds). 2008. Rivers in History. Perspectives on Waterways in Europe and North America. Pittsburgh: University of Pittsburgh Press.

Melosi, Martin. 2000. The Sanitary City. Urban Infrastructure in America from Colonial Times to the Present. Baltimore, London: The John Hopkins University Press.

Melosi, Martin. 2011. Precious Commodity. Providing Water for America's Cities. History of the Urban Environment. Pittsburgh Pa: University of Pittsburgh Press.

Nygård, Henry. 2005. Bara ett ringa obehag?: avfall och renhållning i de fnländska städernas profylaktiska strategier 1830-1930. Åbo: Åbo Akademi. 
Rahikainen, Eljas. 2001. 'Kuohuva vuosisata. Vantaanjoki ja Helsingin vedenotto'. In Simo Laakkonen, Sari Laurila, Pekka Kansanen and Harry Schulman (eds). Näkökulmia Helsingin ympäristöhistoriaan. Kaupungin ja ympäristön muutos 1800- ja 1900-luvuilla. pp. 206-225. Helsinki: Helsingin kaupungin tietokeskus.

Raivo, Petri. 2002. 'The Finnish Landscape and Its Meanings'. Fennia 180: 89-98.

Rajala, Riikka. 2013. 'Likaviemäristä raakavesilähteeksi - Vantaan vesien ympäristöhistoria 1950-luvulta 2010-luvulle'. Ympäristöhistoria Journal of Finnish Environmental History 1:7-21.

Rosenberg, Antti. 2000. Järvenpään historia. Kylästä kaupungiksi 1951-1985. Rosenberg: Jyväskylä.

Schönach, Paula. 2004. Saippuakuplista suojeluun: Vantaanjoen ympäristöhistoriaa vuosilta 1945-1963. Tutkimuskatsauksia, 6. Helsinki: Helsingin kaupungin tietokeskus.

Schönach, Paula. 2007. 'Vantaanjoen suojeluyhteistyö toisen maailmansodan jälkeen' Historiallinen Aikakauskirja 105 (1): 22-33.

Soll, David. 2012. 'City, Region, and in Between: New York City's Water Supply and the Insights of Regional History'. Journal of Urban History 38 (2): 294-318.

Tammela, Kauko. 1959. 'Levien aiheuttamista haju- ja makuhäiriöistä Helsingin kaupungin vesijohtovedessä loppukesällä 1959'. Kunnallistekniikka No 55: 328-331.

Tammela, Kauko. 1983. 'Vesistön käyttö'. In Olli Kauppila (ed.) Vantaanjoki. Vantaanjoen ja Helsingin seudun vesiensuojeluyhdistyksen 20-vuotisjuhlakirja. pp. 65-75. Helsinki: VHVSY.

Tarr, Joel A. and Gabriel Dupuy (eds). 1988. Technology and the Rise of the Networked City in Europe and America. Philadelphia: Temple University Press.

Tarr, Joel. 1996. The Search for the Ultimate Sink: Urban Pollution in Historical Perspective. Technology and the environment series. Akron (Ohio): University of Akron Press.

Tarr, Joel. 2002. 'The Metabolism of the Industrial City: The Case of Pittsburgh'. Journal of Urban History 28 (5): 511-545.

Taylor, Vanessa. 2013. 'Watershed Democracy or Ecological Hinterland? London and the Thames River Basin, 1947-89'. Paper presented at the workshop 'Rivers, Cities, Historical Interactions', Rachel Carson Center, Munich, February 2013.

Timmerbacka, Ville. 2006. Viemäristä virkistyskeitaaksi. Vantaanjoen tila ja uutisointi 1945-2005. Master Thesis, Department of Social Sciences, University of Tampere.

Turpeinen, Oiva. 1995. Kunnallistekniikkaa Suomessa keskiajalta 1990-luvulle. Helsinki: Kunnallistekninen yhdistys.

Vantaanjoen ja Helsingin seudun vesiensuojeluyhdistys. 1965. Selvitys Vantaanjoen vesistöstä . Julkaisu nro 2. Helsinki: VHVSY.

Vantaanjoen ja Helsingin seudun vesiensuojeluyhdistys. 1967. Toimialueen viemärilaitokset. Julkaisu nro 4. Helsinki: VHVSY.

Vantaanjoen ja Helsingin seudun vesiensuojeluyhdistys. 1972. Vantaanjoen vesistön suojelu . Osa I. Vesistö ja sen käyttö. Julkaisu nro 6. Helsinki: VHVSY.

Vesistönsuojelukomitea 1958. Vesistönsuojelukomitean mietintö 1958:13. Helsinki. (Memorandum of the Water Protection Committee).

Waris, Heikki. 1973. Työläisyhteiskunnan syntyminen Helsingin Pitkänsillan pohjois- 
puolelle. 2nd revised edition, originally published 1932. Helsinki: Weilin+Göös.

Winiwarter, Verena. 2001. 'Where Did All the Waters Go? the Introduction of Sewage Systems in Urban Settlements'. In Christop Bernhardt (ed.) Environmental

Problems in European Cities in the 19th and 20th Century. pp. 105-119. Münster; New York; München; Berlin: Waxmann. 